\title{
IAMJ
}

INTERNATIONAL

AYURVEDIC

MEDICAL JOURNAL

ISSN: 2320-5091

Impact Factor: 6.719

\section{ANATOMICAL APPROACH TO MODE OF ACTION OF NASYA W.S.R SNEHANA NASYA - A REVIEW STUDY}

\section{Shanakarling Maidaragi ${ }^{1}$, Supriya Guddad ${ }^{2}$}

Associate Professor Department of Shareera Rachana S V M Ayurvedic Medical College Ilkal-587125, Karnataka, India

Assistant professor Department of Panchakarma, S V M Ayurvedic Medical College Ilkal-587125, Karnataka, India

Corresponding Author: drshankar.anatomy@gmail.com

https://doi.org/10.46607/iamj1709032021

(Published online: March 2021)

Open Access

(C) International Ayurvedic Medical Journal, India 2021

Article Received: 18/02/2021 - Peer Reviewed: 26/02/2021 - Accepted for Publication: 04/03/2021

(A) Check for updates

\section{ABSTRACT}

In Ayurveda there are two folds of treatment one is Shodhana and the other is Shamana. Shodhana includes panchakarma which is used to purify the body by removing the vitiated doshas of body. All five Panchakarma procedures act specifically on specific doshas. Sneha nasya i.e. administration of medicated oil through nasal cavities is one of the Panchakarma procedure which specifically used to treat Urdhva Jatrugata Vyadhis. According to Ayurveda, nose is the gateway of Shiras -brain, it can provide direct connection between brain and nasal mucosa and can transfer the administrated medicines from nose directly to cranial cavity. This is why Nasya karma is used to treat diseases of head region which are generated by vitiated Kapha and Vata dosha. Medicated Sneha has lipid soluble substances which gets easily absorbed by mucous membrane of nasal cavity and get easily transmitted to cranial cavity. The anatomical connectivity of nose with cranial cavity has been proved by modern science also. The direct nerve supply from CNS and the rich vascular supply to nasal cavity help to understand probable mode of action of Nasya Karma.

Keywords: Nasyakarma, Snehana nasya, Shiras 


\section{INTRODUCTION}

From ancient era nose is an important drug delivery route. There are various references found in Ayurvedic texts which indicate that this route is used for delivering drug to local and for the systemic action of drug. Maharshi Atreya has given first place for Shirovirechana. Nasya is one of the important Panchakar$m a$ which is routinely practiced at OPD level by Shalakya and Panchakarma specialties in wide range of diseases. It is used for prevention and treatment of various diseases. Nasya is the method in which various form of drugs like medicated oil, powder and smoke will be made to pass through the Nasa Marga. Nasya is mainly useful in the diseases of Urdwa jatrugata region. Various literature from the Ayurveda text clearly indicates that the drug administer through the nose may act on the Shiras. Delivery of drug to Brain from nasal route may occur through olfactory neuro epithelium.

\section{Nasya}

According to Sushrutha, administration of medicine or medicated oil (siddha sneha) through the nostrils is called nasya karma. The word Nasthaha also indicates Nasya karma. It is basically used for the Shodhana of upper part of the body. In Ayurveda head region is considered the most important part of the body which is the site of Kapha dosha. In Kapha predominant urdhva jatrugata vyadhis, nasya is considered as the best Panchakarma. Nose is the gate way of shiras, The drug adminsterd through nose as Nasya reaches Shringhataka -a sira marma through the Nasa srotas $\&$ also reaches to junctional places of siras of netra, srotra, kantha etc and remove morbid doshas present above the supraclavicular region and expel them from the uttamanga as the pith (ishika) is taken out after removing the fibrous coating of munja (Type of grass) adhered to it ${ }^{1}$.

\section{Types of Nasya}

Acharya charaka has classified the Nasya according to the form of medication used for the Nasya karma. They are navana, avapidana, dhmapana, dhuma and prathimarsha nasya ${ }^{2}$. Acharya vagbhata had classified nasya types according to its action on the body. They are the three types- rechana, tarpana and shama- $n a^{3}$.According to Sushurta. Nasya is basically of two types shirovirechana and snehananasya. Snehnanasya of sushruta is same as that of Navana nasya of Charaka.

\section{Snehana Nasya}

Sneha dravyas like Ghrita,Taila or other Siddha Sneha (medicated oils) can be used for Nasya karma. Sushruta has further described that the one which is used in Shirahsunyata, the one which gives strength to the neck, shoulder and chest regions, the one which increases the eye sight, that Snehanasya is known as Nasya in general ${ }^{4}$.Vagbhata has concluded that Taila is the best Sneha to use on the daily basis for the Nasya karma ${ }^{5}$. As head is the site of the kaphadosha and taila has kaphahara properties and taila reduces the vitiated kapha dosha. Another form of snehanasya is described under the headings of Marsha nasya and Pratimarsha Nasya. In these types of Snehanasya, different Snehamatra is used. According to Vagbhata, 2 bindu of Sneha dravya in each nostril is given for Pratimarsha Nasya and 10 Bindu(drops) of Sneha in each nostril is given in for Marshanasya ${ }^{6}$.Marsha Nasya is given in the diseased condition. Here age and season should be considered. Pratimarsha sneha nasya can be given twice a day - in the morning and evening to any person in any season. Marsha Nasya is highly effective as its dose is more than pratimarsha nasya. Pratimarsha Nasya is less potent and take long time to act but has similar effect as that of the Marsha Nasya. Marsha snehanasya may have some complications due to improper administration but pratimarsha Nasya has no side effects or complication as such ${ }^{7}$.

To understand the actions of Snehanasya, we should know nasal anatomy in detail. Similarly, physiology of the nose in absorption of the Sneha Nasya is also very important in understanding the action of the Sneha Nasya.

Anatomical aspect of Nasal Cavity related to mode of action Nose is an organ of upper respiratory system having external and internal portion, also receptor organ for olfaction. External-Supporting framework of bone \& hyaline cartilage. Internal-Large cavity in Ant Aspect of skull. 
Nasal mucosa: Consists of Two types of mucosa i.e., Olfactory and respiratory mucosa.

Olfactory mucosa - occupies sup part of nose \& extending to superior part of middle nasal concha.

Respiratory mucosa - rest of the cavity. The total surface area available in the nasal mucosa is estimated to be about $180 \mathrm{~cm}^{2}$, of which $10 \mathrm{~cm}^{2}$ is olfactory mucosa and $170 \mathrm{~cm}^{2}$ is the richly vascularised respiratory mucosa

Olfactory Mucosa having 3 type of cells

1. Olfactory receptors (O.R)- Its order neurons \&Bipolar neurons. Dendrites consists of olfactory cilia with olfactory rod. Axons project through the cribriform plate of ethmoid bone and ends in the olfactory bulb which is the part of anterior cranial fossa.

2. Supporting cells-Columnar epithelial cell, provides physical support, nourishment and electrical insulation.
3. Basal cells Are stem cells, lies between supporting cells, produces new Olfactory receptors.

Olfactory mucosa also consists of mucus producing glands called Bowmans's glands. These produces the mucus that moistens olfactory epithelium and dissolve the odorants so that transduction can occur. These glands \& supporting cells are innervated by branches of Facial nerve(VII cranial) Impulse in this nerve in turn stimulates lacrimal gland(tears), and nasal mucus gland(runny nose) The nerve cells of the olfactory epithelium project into the olfactory bulb of the brain, which provides a direct connection between the brain and the external environment. Paranasal sinuses like frontal, maxillary, sphenoid and ethmoidal are opens into nasal cavity through its lateral wall. General sensory nerves of nasal cavity are derived from general efferent fibers of trigeminal nerve which are distributed to whole of the lateral wall.

\section{Olfactory pathway}

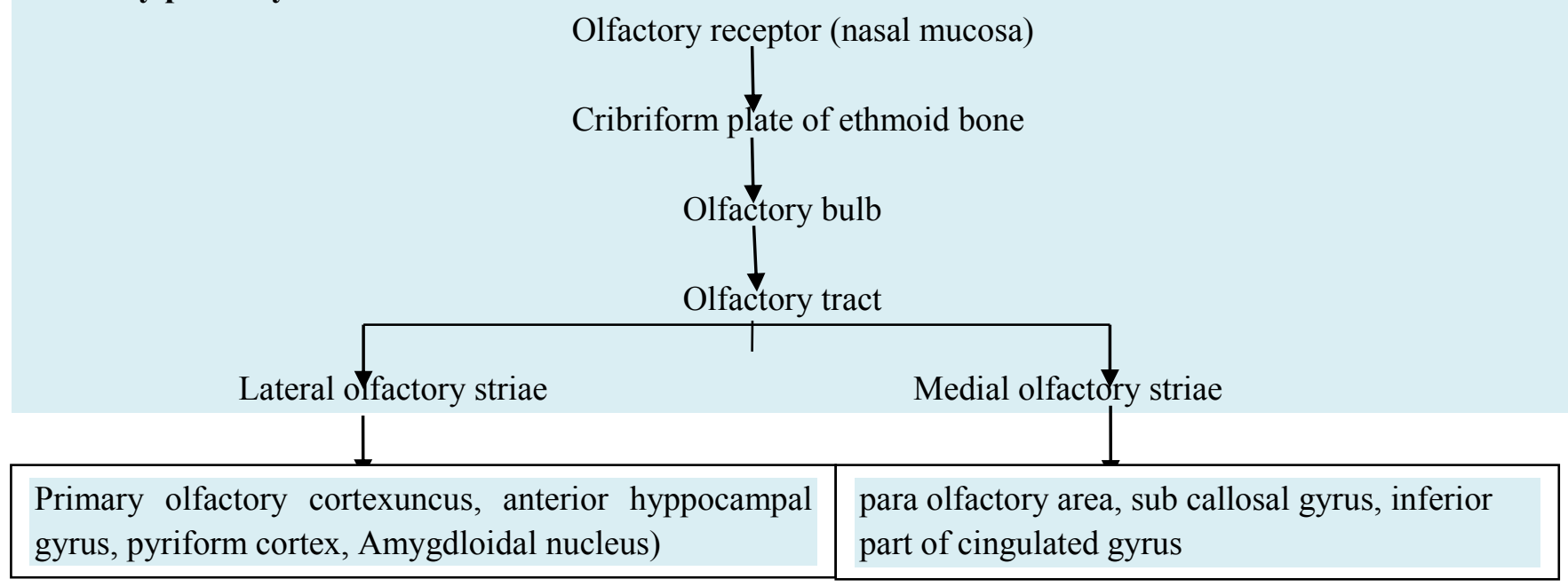

Trigeminal pathway

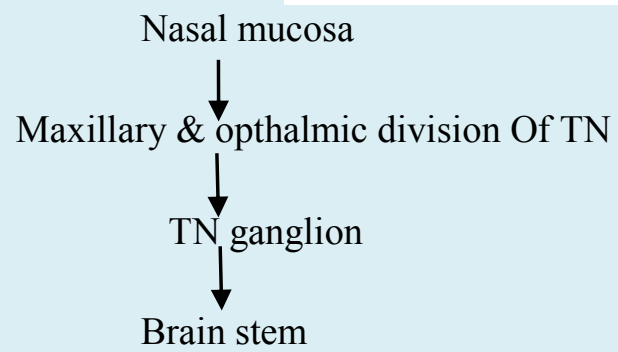


The pharmacodynamics of Nasyakarma can be explained in light of modern anatomical and physiological studies as follows

1. Neurological pathway

2. Diffusion method

3. Vascular pathway

\section{Neurological pathway}

By administrating nasya karma three cranial nerves are stimulated i.e., Olfactory, Trigeminal and Fascial nerve. The experimental stimulation of olfactory nerves causes stimulation in higher centers of brain i.e. Limbic system consisting mainly Hypothalamus, Amygdaloidal complex, Epithalamus, Basal ganglia.

Hypothalamus- It is considered as the head nucleus of Autonomic nervous system (Sympathetic \& Para sympathetic) so all visceral activities like HR, BP, vasodilatation and contraction, G I movements etc. Regulation of hormone synthesis- it is master of endocrine gland \& controls pituitary gland. Regulation of emotional and behavioral patterns together with limbic system. Regulates body temperature.

Amygdaloidal -Function is almost same as of Hypothalamus

Epithalamus Consists of Pineal gland and Habenular nuclei. Pineal gland is an endocrine gland secrets melatonin. Habenular nuclei- is responsible for emotional response to odor.

Basal ganglia-Controls body movements

\section{Diffusion method}

Lipid soluble substances have greater affinity for absorption through the cell wall of nasal mucosa. Thus, Navana Nasya is superior to all the varieties. The cilia $\&$ body of the olfactory cells contains relatively large quantity of lipid materials" this could explain why a substance must be lipid soluble to cause marked stimulation of an olfactory cell.

\section{Vascular pathway}

The large mucosal surface covered with a rich vascular bed of highly permeable capillaries creates an opportunity for intranasal medication delivery. For this reason, when medication of proper concentration and molecular character are delivered on to the nasal mucosa, they are rapidly transported and delivered to the circulation. This vascular path is also possible by the pooling of nasal blood into the facial vein the facial vein has no valves, it freely communicates with cavernous sinus of intracranial circulation through deep facial vein \& pterygoid plexus. Such pooling of blood from nasal veins to venous sinuses of the brain is more likely to occur in head lowering position.

\section{DISCUSSION}

There are many factors responsible for nasal absorption like bioavailability, first pass metabolism, lipophilicity particle size, position, $\mathrm{Ph}$ and dose. Nasally delivered medications avoid the gut so do not suffer first pass metabolism. Lipid Loving." Cellular membranes are composed on layers of lipid material. Drugs that are lipophilic are easily and rapidly absorbed across the mucous membraneHence Navana nasya is superior. Modification of drug structure is also important in absorption. Lower the molecular weight higher the absorption. To improve nasal residence time, Position during administration of Nasya is important. By using high viscosity agents and mucoadhesive substances also absorption of dravya can be increased.

\section{CONCLUSION}

Three cranial nerves are stimulated by Nasya karma Olfactory, Trigeminal \&Fascial nerve. The drug administered through nasa causes stimulation in higher centers of brain. Lipid soluble substances have grater affinity for absorption through the cell wall of nasal mucosa. Proper molecular weight, liphophilicity \& drug concentration are very important for absorption. Using absorption enhancer, the bioavailability of large molecules can be improved through nasal route Transmucosal delivery of drugs through olfactory and trigeminal pathways to brain bypassing BBB is referred as the direct IN drug transportation to brain. This is the only route through which brain is connection with outside environment. Thus, Navan nasya is superior to all the verities 


\section{REFERENCES}

1. Vagbhata.Astanga Hrdayam with Sarvanga Sundara and Ayurveda Rasayana commentary-edited by vaidya Bhishagacharya Harishastri Paradkar Chaukambha Krishnadas Academy. Varanasi.A.hr Ni

2. Vd Kaviraj Atridev Gupt Astangahrudaya of Acharya Vagbhata with Hindi commentary, Sutrasthana (20/1), Chaukhamba Sanskrit Samsthana, Varanasi, Vi. San.2062, 127.

3. Pt Kashinath S and Dr Gorakhnath C. (Reprint 2004). Charaka Samhita by Acharya Agnivesh with hindi commentary. Siddhisthana, (9/88), Chaukhamba Bharati Academy,Varanasi, 1070.

4. Dr Anantarama S. (2006). Sushruta Samhita of Acharya Susruta with hindi commentary, Chikitsasthana (40/22), Chaukhambha surabharathi Prakashana, Varanasi, reprint edition, 495.

5. Vd Kaviraj Atridev Gupt. (2006). Ashtangahrudaya of Acharya Vagbhata with Hindi commentary. Sutrasthana 21/23, Sanskrit Sansthana, Varanasi, Vi.San, 148.

6. Kaviraj Atridev Gupt Ashtangahridaya of Acharya Vagbhata with hindi commentary by,Sutrasthana 27/9,Sanskrit Sansthana, Varanasi,Vi.San 148.

7. Vd Haridas and S Kasture. (1999). Ayurvediya Panchakarma Vigyana, Nasya Vidnyanaadhyaya, Shree Baidyanath Prakashana, Nagpur, 501.

\section{Source of Support: Nil \\ Conflict of Interest: None Declared}

How to cite this URL: Shanakarling Maidaragi \& Supriya Guddad: Anatomical Approach To Mode Of Action Of Nasya W.S.R Snehana Nasya- A Review Study. International Ayurvedic Medical Journal \{online\} 2021 \{cited March, 2021\} Available from: http://www.iamj.in/posts/images/upload/620_624.pdf 